\title{
Flux of nutrients and heavy metals from the Melai River sub-catchment into Lake Chini, Pekan, Pahang, Malaysia
}

\author{
Muhd Barzani Gasim • Sahibin Abd. Rahim • Mohd Ekhwan Toriman • \\ Wan Mohd Razi Idris • Tukimat Lihan • Zulfahmi Ali Rahman • \\ Azman Hashim • Norhadilla Hadib
}

Received: 20 July 2011 / Accepted: 16 August 2012/Published online: 7 September 2012

(C) The Author(s) 2012. This article is published with open access at Springerlink.com

\begin{abstract}
This study was carried out to determine the flux of nutrients and heavy metals from the Melai sub-catchment into Lake Chini through the process of erosion. Melai River is one of the seven feeder rivers that contributed to the present water level of Lake Chini. Three properties of soils, such as particle size, organic matter content, and soil hydraulic conductivity and three chemical soil properties, such as available nutrients, dissolved nutrients, and heavy metals, were analyzed and interpreted. Potential soil loss was estimated using the revised universal soil loss equation model. The results show that the soil textures in the study area consist of clay, silty clay, clay loam, and sandy silt loam. The organic matter content ranges from 3.40 to $9.92 \%$, while the hydraulic conductivity ranges from 5.2 to $25.3 \mathrm{~cm} / \mathrm{h}$. Mean values of available $\mathrm{P}, \mathrm{K}$, and $\mathrm{Mg}$ amount was $8.5 \pm 3.7 \mu \mathrm{g} / \mathrm{g}, \quad 24.5 \pm 3.4 \mu \mathrm{g} / \mathrm{g}, \quad$ and $20.7 \pm 18.6 \mu \mathrm{g} / \mathrm{g}$, respectively. The highest concentration of soluble nutrients was $\mathrm{SO}_{4}^{-2}(815.8 \pm 624.1 \mu \mathrm{g} / \mathrm{g})$, followed by $\mathrm{NO}_{3}{ }^{-}-\mathrm{N} \quad(295.5 \pm 372.7 \mu \mathrm{g} / \mathrm{g}), \mathrm{NH}_{4}{ }^{+}-\mathrm{N}$ $(24.5 \pm 22.1 \mu \mathrm{g} / \mathrm{g})$ and $\mathrm{PO}_{4}{ }^{3-}(2.0 \pm 0.8 \mu \mathrm{g} / \mathrm{g})$. The rainfall erosivity value was $1658.7 \mathrm{MJ} \mathrm{mm} / \mathrm{ha} / \mathrm{h} /$ year. The soil erodibility and slope factor ranges from 0.06 to 0.26 ton $\mathrm{h} / \mathrm{MJ} / \mathrm{mm}$ and 7.63 to 18.33 , respectively. The rate of soil loss from the Melai sub-catchment in the present condition
\end{abstract}

M. B. Gasim ( $\square)$ · S. Abd. Rahim - W. M. R. Idris · T. Lihan · Z. A. Rahman · A. Hashim · N. Hadib

School of Environmental and Natural Resource Sciences, Faculty of Science and Technology, Universiti Kebangsaan Malaysia, 43600 Bangi, Selangor, Malaysia

e-mail:dr.zani@ukm.my

M. E. Toriman

School of Social, Development and Environmental Studies, Faculty of Social Sciences and Humanities, Universiti Kebangsaan Malaysia, 43600 Bangi, Selangor, Malaysia is very low (0.0028 ton/ha/year) to low (18.93 ton/ha/year), and low level flow of nutrients and heavy metals, indicating that the Melai River was not the contaminant source of sediments, nutrients, and heavy metals to the lake.

Keywords Heavy metals - Melai river sub-catchment . Nutrient $\cdot$ Soil erosion $\cdot$ Soil loss

\section{Introduction}

Without vegetation cover, the soil surface can be severely eroded by heavy rain or rainstorms (Batie 1983). Because vegetation offers natural protection from the direct impact of rainfall, it can markedly reduce the amount of material eroded from the soil surface. The degree of soil erosion is relatively higher in dipterocarp hill forests compared with lowland areas (Baharuddin 1988) or other land uses (Lopez et al. 1998). Bower (2010) highlighted the processes between natural resources, urbanization and their impact to the environment. Karageorgis et al. (2012) studied the degree of contamination of the sediments, major and minor elements from deltaic plain of the Messolonghi lagoon complex, Greece. Yang et al. (2003) added that the potential for soil erosion varies with different land uses and climates. Numerous studies have been performed on soil erosion; for example, Mohd Ekhwan et al. (2009) compared the processes and effects of infiltration, runoff, and erosion on the soil loss of irrigated land. Srivastava et al. (2010) carried out a study on six different experimental plots with the intention to conserve water and soil erosion along the riparian zone at their study area. Bhattarai and Dutta (2007) and Xu et al. (2008) adopted the revised universal soil loss equation (RUSLE) and GIS model approaches for their analysis of soil loss. Finally, Foster et al. (1981) conducted a study in 
which they converted the RUSLE equation units into meters, while Lee and Lee (2006) used the remotely sensed geospatial technic to estimate soil loss.

Lake Chini consists of seven feeder rivers, among which is the Melai River sub-catchment (Muhammad et al. 2009). The Melai River is located to the south of the lake, and it drains directly into the Lake Chini. According to Sujaul (2009), the Melai River sub-catchment covers approximately 395.72 ha. Through field investigation, the major land uses in this sub-catchment can be categorized into rubber plantation, forest, mining, oil palm plantation, and the settlement of indigenous people. The rubber plantation consists of mature trees, and the forest is a secondary forest. The oil palm plantation and the settlements of the indigenous people are located in the former rubber plantation area. A study by De Neergaard et al. (2008) showed that the management of oil palm plantations involves the use of chemicals such as fertilizers and pesticides, which contribute to the increase of heavy metal flux into open water. Illegal mining activities were prominent during the study period. These activities contributed significantly to the decline of water quality in Lake Chini due to the presence of nutrients and heavy metals. Thus, the main aim of this study is to quantify the amount of nutrients and heavy metals flowing into Lake Chini through the soil erosion of the Melai River sub-catchment. The objectives of this study are (1) to determine the physical and heavy metal properties of the soil, (2) to calculate the amount of soil loss, and (3) to identify the concentration of nutrients and the flow of heavy metals.

\section{Materials and methods}

The study is in the Chini territory under Pekan district of the Pahang state, Malaysia. It is the cover catchment of the Melai River, which is at the southern part of Lake Chini (Fig. 1). The Melai River is one of the seven feeder rivers that drains directly into Lake Chini, which is approximately $53 \mathrm{~m}$ above sea level. There are logging, iron ore mining, and oil palm activities carried out by local residents at the Melai Village upstream of the catchment. Previously, mining was carried out by an appointed mining company, but abandoned once the Government terminated their contract. Selection of sampling stations is based on topography, contour gradient, and type of land use. Soil samples were collected from four sampling locations within this catchment area, five replicates from each station bearing a total of 20 soil samples, which were taken to the lab for further analysis. In situ parameters were observed and noted in the field based on the coordinates of the sampling stations, their canopy cover and the natural conservation practices. The potential soil loss through erosion was calculated for this area using the RUSLE model.

The particle size distribution, organic matter content, hydraulic conductivity, heavy metal, and nutrient contents were determined for the soil samples. Particle size was determined using the pipette method with slight modification (Abdulla 1966). The organic matter content was determined using the gravimetric method (Avery and Bascomb 1982), and the hydraulic conductivity was determined using the falling head method described by Kirkby (1980). The heavy metals were extracted using the wet digestion method with nitric acid with perchloric acid at 3:1 ratio. The available nutrients in the soil were extracted using the double acid extraction method with a mixture of ammonium acetate and acetic acid. The heavy metals in the solution extract were determined using the atomic adsorption spectrophotometry flame technique (AAS) using a 3300 PERKIN ELMER 1967 instrument. The concentration of $\mathrm{NO}_{3}-\mathrm{N}$ was determined by the cadmium reduction method (APHA 1989). The prediction of soil losses was based on rainfall intensities in agricultural areas (Wischmeier and Smith 1965; Wischmeier et al. 1971) and on orthophosphate using the molybdenum blue method developed by Murphy and Riley (1962).

\section{Results and discussions}

Soil organic matter

As a binding agent, organic matter is important in the formation of soil aggregates. Organic matter binds to the clay component, producing an even stronger soil structural stability. Organic matter decomposition produces humic chemicals that interact with clay, thus increasing the binding strength of particles. The formation of good and strong soil aggregates enhances water infiltration through the soil profile, thus reducing surface water flow, which causes erosion. The organic matter content data shown in Table 1 ranges from 3.40 to $9.92 \%$, indicating a higher content at Station 4 followed by Stations 1, 3, and 2 . Stations 1 and 4 each have high clay contents, which can produce strong binding with the organic matter. Station 2, which has the lowest content of organic matter, was a rubber tree plantation where the trees were widely spaced when planted, thus producing low canopy cover. According to Morgan (2005), soil with less than $3.5 \%$ organic matter content is considered weakly aggregated and is easily eroded. Variance analysis indicates a significant difference in organic matter content at the $5 \%$ level among the stations. 


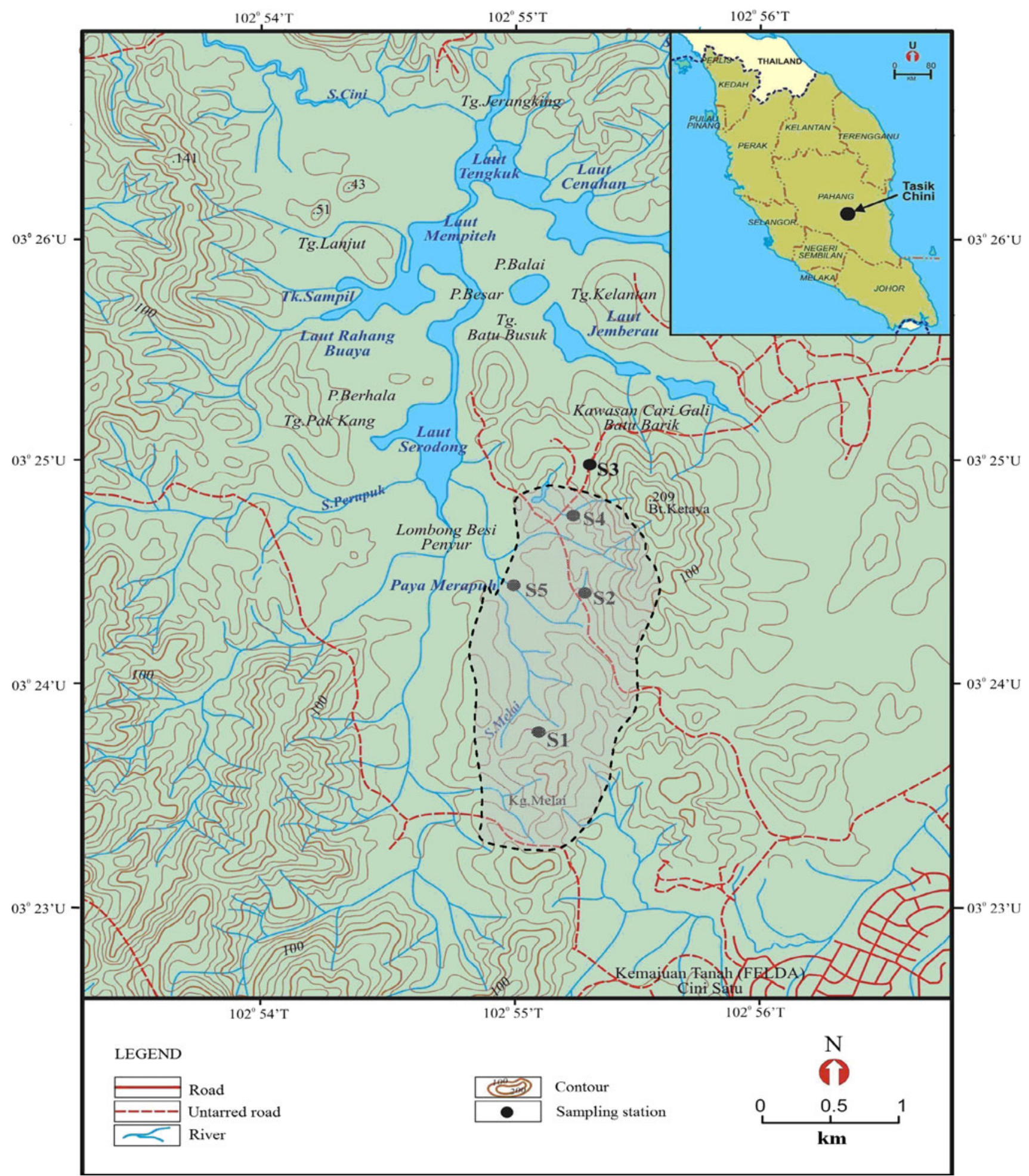

Fig. 1 Map showing the sub-catchment of Melai River and sampling stations

Soil texture

In Table 1, the soil particle size is dominated by the clay fraction at Stations 1 and 4 but is dominated by the silt fraction in Stations 2 and 3. Station 1 recorded the highest clay content, followed by Stations 4, 2, and 3. The silt fractions are approximately the same at Stations 2, 3, and 4 but are lower than at Station 1. The dominant soil texture is clay, followed by clay loam, silty loam, silty clay, and sandy silt loam. 
Table 1 Organic matter contents, size distributions and texture of soils

\begin{tabular}{|c|c|c|c|c|c|c|}
\hline Station & Organic matter $(\%)$ & Mean $(\%)$ & Sand $(\%)$ & Silt (\%) & Clay $(\%)$ & Texture \\
\hline 1 & 7.05 & $7.59 \pm 0.58$ & 20 & 33 & 47 & Clay \\
\hline \multirow[t]{2}{*}{ Forest } & 7.51 & & 10 & 25 & 64 & Clay \\
\hline & 8.20 & & 10 & 22 & 68 & Clay \\
\hline 2 & 2.59 & & 17 & 46 & 37 & Silty clay \\
\hline \multirow[t]{2}{*}{ Rubber } & 4.20 & $3.40 \pm 0.81$ & 24 & 42 & 34 & Clay loam \\
\hline & 3.42 & & 23 & 43 & 34 & Clay loam \\
\hline 3 & 7.03 & & 43 & 43 & 15 & Sandy silt loam \\
\hline \multirow[t]{2}{*}{ Former mine rubber } & 7.67 & $7.17 \pm 0.45$ & 18 & 76 & 7 & Silty loam \\
\hline & 6.81 & & 18 & 31 & 51 & Clay \\
\hline 4 & 9.23 & & 23 & 37 & 40 & Clay \\
\hline \multirow[t]{2}{*}{ Forest } & 13.83 & $9.92 \pm 3.6$ & 19 & 40 & 41 & Clay \\
\hline & 6.70 & & 21 & 38 & 42 & Clay \\
\hline
\end{tabular}

Hydraulic conductivity

Hydraulic conductivity is a measurement of the ease of water infiltration downward during rainfall. A higher soil hydraulic conductivity is essential for reducing the surface water movement that causes erosion. The hydraulic conductivity in the study area ranges from 5.2 to $25.3 \mathrm{~cm} / \mathrm{h}$. Due to the higher sand content, high hydraulic conductivity was recorded at Station 3 (Fig. 2). Hydraulic conductivity is influenced by soil texture, clay minerals, and bulk density. Coarsely textured soils, such as sand and loamy sand, have open pore spaces and are able to drain water faster and more readily (Bocco 1991). Organic matter content is another factor that contributed to the high hydraulic conductivity of Station 3, which had slightly higher concentrations than the other stations.

\section{Available nutrients}

Available nutrient content represents the amount of nutrients in the soil that can be utilized for plant growth. Available nutrients are essential and are normally supplemented through plant fertilization. The fertilizers commonly used include nutrients such as $\mathrm{N}, \mathrm{P}, \mathrm{K}, \mathrm{Ca}$, and $\mathrm{Mg}$. Only the available $\mathrm{P}, \mathrm{K}$, and $\mathrm{Mg}$ were measured in this analysis. In Fig. 3, the mean concentration of $\mathrm{K}$ is the highest $(24.5 \pm 3.4 \mu \mathrm{g} / \mathrm{g})$, followed by $\mathrm{Mg}(20.7 \pm 18.6$ $\mu \mathrm{g} / \mathrm{g})$, and $\mathrm{P}(8.5 \pm 3.7 \mu \mathrm{g} / \mathrm{g})$.

The potassium content in the soil is relatively constant for all four sampling stations, as indicated by the low SD values. The variance test shows that there are no significant differences among the stations. High amounts of K can be contributed to soils by the weathering of minerals that contain $\mathrm{K}$, such as feldspar and mica. The element is then absorbed and held by organic matter at their exchange base (Fortescue 1979) and is released as an available nutrient.

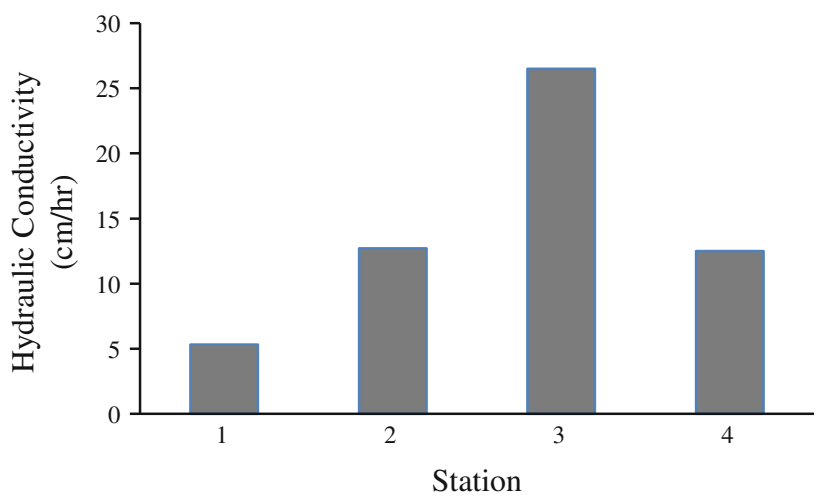

Fig. 2 Hydraulic conductivity of the soil in the study area

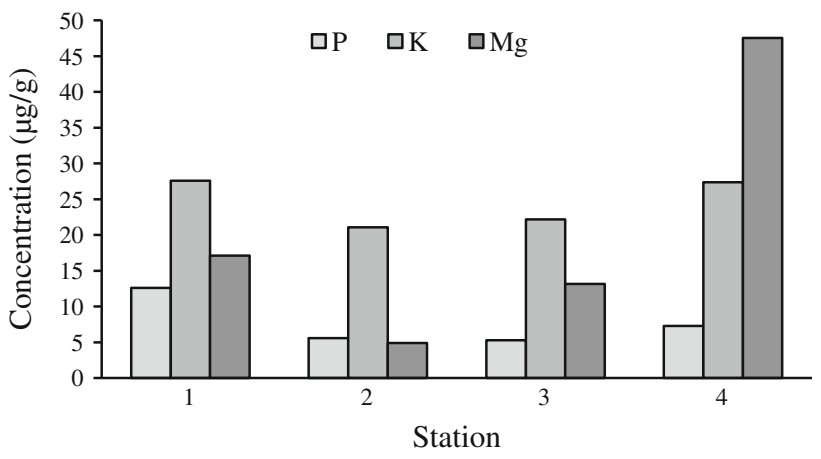

Fig. 3 Available nutrient contents in soil

There is a wide variation in the mean concentrations of $\mathrm{Mg}$, as indicated by its SD, which was significantly different among the stations at the $1 \%$ level. The highest mean concentration is found at Station 4, followed by Station 1; the soils of both stations are under forested land use. The magnesium content in the sedimentary rocks is naturally high, with an average content of approximately $0.5 \%$ (Sujaul 2009). 
Soluble nutrients

Some fractions of the soil nutrients are present in the soluble form. Soluble nutrients are easily transported and are therefore a potential contaminator of bodies of water. As shown in Table 2, $\mathrm{SO}_{4}^{-2}$ is the most soluble nutrient, with a mean and SD of $815.8 \pm 624.1 \mu \mathrm{g} / \mathrm{g}$. $\mathrm{SO}_{4}^{-2}$ is followed by $\mathrm{NO}_{3}{ }^{-}-\mathrm{N}$, with a mean and $\mathrm{SD}$ of $295.5 \pm 372.7 \mu \mathrm{g} / \mathrm{g}$; $\mathrm{NH}_{4}{ }^{+}-\mathrm{N}$, with a mean and SD of $24.5 \pm 22.1 \mu \mathrm{g} / \mathrm{g}$; and $\mathrm{PO}_{4}{ }^{3-}$, with the lowest mean and $\mathrm{SD}$ of $2.0 \pm 0.8 \mu \mathrm{g} / \mathrm{g}$. Station 1 recorded the highest concentration of all of the soluble nutrients; however, the SD is too high, indicating the presence of an anomaly in the sampling substation. It is, however, valid to include any possible variation at a sampling station. Due to the high SD, there are no significant differences in the particular nutrient concentrations among the stations, with $P$ values of $0.133,0.107,0.124$, and $0.091(p>0.05)$ at Stations $1-4$, respectively. The higher $\mathrm{N}$ than $\mathrm{P}$ concentration indicates the importance of the $\mathrm{N}$ component in organic matter, which is more readily leached from the soil than $\mathrm{P}$.

Soluble $\mathrm{PO}_{4}{ }^{3-}$ presents the lowest concentrations at the sampling stations, which can be attributed to its low solubility in the soil. The solubility of soil is influenced by soil pH. $\mathrm{PO}_{4}{ }^{3-}$ is more soluble in soil with a $\mathrm{pH}$ between 5.5 and 7 , and its solubility decreases when the $\mathrm{pH}$ falls below 5.5 or exceeds $\mathrm{pH}$ 7. At low $\mathrm{pH}, \mathrm{PO}_{4}{ }^{3-}$ reacts with $\mathrm{Fe}$ and aluminum to form a complex that fixes the $\mathrm{PO}_{4}{ }^{3-}$ (Tisdale and Nelson 1975).

\section{Heavy metals content}

Table 3 shows that Mn represents the highest heavy metal concentration in the soil, followed by $\mathrm{Pb}, \mathrm{Cr}, \mathrm{Cu}, \mathrm{Co}$, and $\mathrm{Cd}$. The highest concentration of $\mathrm{Mn}$ is found at Station 3, with a mean and SD of $932.93 \pm 65.39 \mu \mathrm{g} / \mathrm{g}$, and the lowest level is at Station 2, with a mean and SD of
$18.05 \pm 2.40 \mu \mathrm{g} / \mathrm{g}$. A high $\mathrm{Mn}$ concentration is normally associated with the formation of secondary iron ore in the form of goethite nodules. High $\mathrm{Pb}$ concentrations are also recorded at Station 3, with a mean and SD of $259.71 \pm 76.89 \mu \mathrm{g} / \mathrm{g}$, while the lowest is found at Station 4, with a mean and SD of $30.0 \pm 5.86 \mu \mathrm{g} / \mathrm{g}$. The mean at Station 3 is already within the range of the critical concentration proposed by Kabata-Pendias and Pendias (2001), at $100-400 \mathrm{mg} / \mathrm{kg}$. Station 3 is a former iron mining area, where rock blasting and crushing were conducted to separate the iron from its ore. According to Sahibin et al. (2009), the blasting and crushing of rocks containing ore will produce heavy metals such as $\mathrm{Mn}, \mathrm{Pb}, \mathrm{Cu}$, and $\mathrm{Cd}$ in the form of dust. This dust is eventually deposited on the surface of water bodies and soil, leading to the risk contamination.

The heavy metals $\mathrm{Cr}, \mathrm{Cu}, \mathrm{Co}$, and $\mathrm{Cd}$ were found to be within the normal concentrations in soils (Kabata-Pendias and Pendias 2001). The copper and Co concentrations are high at Station 3. These high values are associated with the former iron mining activities. These metals probably precipitated together with $\mathrm{Fe}$ and $\mathrm{Mn}$ during the formation of the iron concretion.

Soil loss prediction (RUSLE)

Soil loss prediction for the study area was carried out with the widely used RUSLE soil erosion model. With this model, the amount of soil loss $(A)$ can be obtained by measuring five key factors: rainfall erosivity $(R)$, soil erodibility $(K)$, slope length and steepness (LS), plant cover $(C)$ and conservation practice $(P)$. The RUSLE equation model is as follows: $A=R$. K. LS. C. P.

\section{Erosivity factor $(R)$}

Rainfall data collected from the FELDA Chini 2 rainfall station were used to calculate rainfall erosivity for the
Table 2 Soluble nutrient content in soil of the study area $(\mu \mathrm{g} / \mathrm{g})$

\begin{tabular}{llrrr}
\hline Station & $\mathrm{PO}_{4}^{-3}$ & $\mathrm{SO}_{4}^{-2}$ & $\mathrm{NO}_{3}{ }^{-}$ & $\mathrm{NH}_{4}{ }^{+}-\mathrm{N}$ \\
\hline 1 & & & & \\
Mean & 1.65 & 1743.33 & 850.00 & 57.67 \\
$\mathrm{SD}$ & 0.64 & 1220.22 & 795.32 & 42.02 \\
2 & & & & 14.20 \\
Mean & 1.51 & 590.00 & 149.00 & 4.07 \\
$\mathrm{SD}$ & 0.22 & 75.50 & 55.51 & 11.80 \\
3 & & & & 11.10 \\
Mean & 1.60 & 540.00 & 44.00 & 10.54 \\
$\mathrm{SD}$ & 0.28 & 353.69 & & 2.95 \\
4 & & & 139.00 & 54.44 \\
Mean & 3.23 & 390.00 & & \\
$\mathrm{SD}$ & 1.14 & 180.00 & & \\
\hline
\end{tabular}



in soils $(\mu \mathrm{g} / \mathrm{g})$
Table 3 Heavy metals content

\begin{tabular}{lrrrrrr}
\hline Station & $\mathrm{Mn}$ & $\mathrm{Pb}$ & $\mathrm{Cr}$ & $\mathrm{Cu}$ & $\mathrm{Co}$ & $\mathrm{Cd}$ \\
\hline 1 & & & & & & \\
Mean & 108.23 & 36.04 & 27.95 & 12.74 & 9.82 & 1.51 \\
$\mathrm{SD}$ & 31.90 & 18.23 & 5.82 & 3.80 & 7.17 & 0.26 \\
2 & & & & & \\
Mean & 18.05 & 30.16 & 3.61 & 2.59 & 9.02 & 0.91 \\
SD & 2.40 & 8.68 & 0.88 & 1.08 & 1.43 & 0.28 \\
3 & & & & & \\
Mean & 932.93 & 259.71 & 18.94 & 50.25 & 13.99 & 1.32 \\
SD & 65.39 & 76.89 & 1.89 & 9.43 & 2.41 & 0.32 \\
4 & & & & & \\
Mean & 185.19 & 30.00 & 6.08 & 2.16 & 9.62 & 1.16 \\
SD & 172.96 & 5.86 & 0.35 & 1.05 & 1.85 & 0.71 \\
\hline
\end{tabular}

Tasik Chini area. The mean annual rainfall calculated from 1997 to 2006 is $2125.7 \mathrm{~mm}$. The formula used for this calculation is from Morgan (2005) and Roose (1977), the details of which are shown in Table 4 . The value of mean rainfall $(P)$ was inserted into the formula, and the best estimated value of rainfall erosivity was obtained, which is 1327.9 MJ mm/ha/h/year.

\section{Erodibility factor $(K)$}

The erodibility factor is calculated using the nomograph formula given below. The erosivity values were produced using this formula (Table 5). The soil erodibility factor ranges from 0.01 to $0.19 / \mathrm{MJ} / \mathrm{mm}$. The highest erodibility factor is found at Station 2, followed by Stations 3, 4, and 1. The high erodibility factor at Station 2 can be attributed to the combined effect of the soil texture with a low percentage of organic matter.
Table 4 Rainfall erosivity calculated for Tasik Chini

\begin{tabular}{lll}
\hline Method & $\begin{array}{l}\text { Formula } \\
\text { (in metric unit) }\end{array}$ & $\begin{array}{l}R \text { value } \\
(\mathrm{MJ} \mathrm{mm} / \mathrm{ha} / \mathrm{h} / \text { year })\end{array}$ \\
\hline $\begin{array}{l}\text { Morgan } \\
(2005)\end{array}$ & $\frac{(9.28 P-8838) \times 75}{1000}$ & 816.6 \\
Roose $(1977)$ & $0.5 P \times 1.73$ & 1838.7 \\
Best estimate & & 1327.9 \\
\hline
\end{tabular}

Rainfall mean $(P)=2125.7 \mathrm{~mm}$

Source: FELDA Chini 2 rainfall data for observation period from 1997 to 2006

Station 4 (Table 6). It is obvious that the high LS factor for Station 1 is due to the degree of steepness.

$\mathrm{LS}=\left(0.065+0.045 S+0.0065 S^{2}\right) \times \sqrt{\frac{L}{22.13}}$

$K=\frac{\left(2.1 \times 10^{-4}(12-\mathrm{OM} \%)\left(N_{1} \times N_{2}\right)^{1.14}+3.25(\mathrm{~S}-2)+2.5(P-3)\right)}{100}$

Slope length and steepness factor (LS)

The sampling station sites are in areas with different topographies. Station 1 is on a $36.4 \%$ slope with a length of approximately $70 \mathrm{~m}$; Station 2 is at $25.5 \%$, with a slope length of $100 \mathrm{~m}$; Station 3 is at $18.2 \%$, with a slope length of $140 \mathrm{~m}$; and Station 4 is at $28.3 \%$, with a slope length of $90 \mathrm{~m}$. The slope lengths and steepness factors (LS), calculated using the formula as shown below, are 18.3 for Station 1, 11.5 for Station 2, 7.6 for Station 3, and 13.2 for
Land canopy cover $(C)$

The field observations indicate closed canopy coverage in the forested areas at Stations 1 and 4. The ground is covered by a litter layer together with undergrowth. Stations 2 and 3 are both matured rubber plantations; however, they have no closed canopy cover. In addition, there is lesser litter layer on the ground at Stations 2 and 3 compared with 1 and 4. The assigned CP value for Stations 1 and 4, which have a closed canopy cover of forested area, based on 
Table 5 Erodibility factor of soil $(K)$

\begin{tabular}{|c|c|c|c|c|c|c|c|}
\hline \multirow[b]{2}{*}{ Station } & \multicolumn{2}{|l|}{$\mathrm{N}_{1}$} & \multicolumn{5}{|l|}{$\mathrm{N}_{2}$} \\
\hline & $\mathrm{Z}+\mathrm{VFS}(\%)$ & CS $(\%)$ & $\mathrm{Z}+\mathrm{VFS}+\mathrm{CS}(\%)$ & $\mathrm{OM}(\%)$ & (S) & $\mathrm{HC}(\mathrm{cm} / \mathrm{h})$ & $\mathrm{K}_{\text {erod }} \mathrm{th}(\mathrm{MJ} \mathrm{mm})^{-1}$ \\
\hline 1 & 31.46 & 13.58 & 45.04 & 7.59 & 2 & 4 & 0.06 \\
\hline 2 & 51.54 & 21.10 & 72.65 & 3.40 & 2 & 2 & 0.19 \\
\hline 3 & 53.48 & 26.29 & 79.78 & 7.17 & 2 & 1 & 0.09 \\
\hline 4 & 44.93 & 20.99 & 65.92 & 9.92 & 2 & 2 & 0.01 \\
\hline
\end{tabular}

$Z$ silt, $C S$ coarse sand, $V F S$ very fine sand, $O M$ organic matter, $H C$ or $P$ hydraulic conductivity, $K_{\text {erod }}$ erodibility rate, $S$ soil structure

Table 6 Slope length and steepness (LS) factor of the study area

\begin{tabular}{lllr}
\hline Station & Slope length $(\mathrm{L})(\mathrm{m})$ & Steepness $(\mathrm{S})(\%)$ & \multicolumn{1}{c}{ LS } \\
\hline 1 & 70 & 36.4 & 18.3 \\
2 & 100 & 25.5 & 11.5 \\
3 & 140 & 18.2 & 7.6 \\
4 & 90 & 28.3 & 13.2 \\
\hline
\end{tabular}

Source: Morgan (2005)

Roslan and Tew (1997), is 0.010. For Stations 2 and 3, the $C$ value for rubber plantations, based on Morgan (2005), is 0.2 . The individual $C$ factor for forested areas is 0.001-0.002 (Morgan 2005).

\section{Conservation practice $(\mathrm{P})$}

Natural conservation practices in forested areas that aim for erosion control greatly depend on the existing environmental conditions. Examples of these conditions are the litter layer, which acts as a cover protecting the soil from the impact of direct rainfall; the rooting system, which helps to bind the soil; and canopy cover and undergrowth, which reduce the surface movement of particulates. In forested areas, the conservation factor is $P=C \times 0.15$, where $C$ is the plant canopy value. In rubber plantations, certain mechanical soil conservation measures are practiced, including contouring multiplied by 0.6 , contour stripping multiplied by 0.35 , and terracing multiplied by 0.15 (Morgan et al. 1982). The rubber trees in the study area were planted according to the contour stripping method. The $P$ value assigned for this practice is $P=C \times 0.35$.
Predicted soil loss

The amount of predicted soil loss (Table 7) within the catchment of Melai River is considered low to very low according to the Malaysian soil loss tolerance guidelines. The range of soil loss in the study area is 0.00003-40.62 t/ha/year. The higher soil loss at Station 2 is due to the combined effect of high soil erodibility and a lack of canopy and ground cover. This station is located on the dumping ground of a former mining area. Station 2 has the highest predicted soil loss, followed by Stations 3, 1, and 4 .

Available nutrient flow

The concentration of available nutrients (Table 8) in the sampled soils is low; therefore, the amount of nutrient flow from the Melai sub-catchment into Lake Chini is expected to be low. The $\mathrm{P}$ and $\mathrm{K}$ concentrations are fairly consistent, but there is a wide variation in $\mathrm{Mg}$ among the stations. The highest amount of nutrient flow into Lake Chini is from Station 2, followed by Stations 3, 1, and 4. The total amount of $\mathrm{P}, \mathrm{K}$, and $\mathrm{Mg}$ flow from this sub-catchment is $81.8 \mathrm{~g} / \mathrm{ha} /$ year, $1140.0 \mathrm{~g} / \mathrm{ha} /$ year, and $367.2 \mathrm{~g} / \mathrm{ha} /$ year, respectively.

Soluble nutrient flow

The total soluble nutrient flow into the lake is high at Stations 2 and 3, but relatively low at Stations 1 and 4. In terms of individual nutrients, $\mathrm{SO}_{4}{ }^{2-}$ is the highest, followed by $\mathrm{NO}_{3}{ }^{-}-\mathrm{N}, \mathrm{NH}_{4}{ }^{+}-\mathrm{N}$, and $\mathrm{P}$, with values of $30860.0 \mathrm{~g} / \mathrm{ha} /$ year, $6614.3 \mathrm{~g} / \mathrm{ha} /$ year, $727.5 \mathrm{~g} / \mathrm{ha} /$ year, and

Table 7 Predicted soil loss $(A)$ within the catchment of Melai River (t/ha/year)

\begin{tabular}{llllllc}
\hline Station & $R$ & $K$ & LS & $C$ & $P$ & \multicolumn{1}{c}{$A$} \\
\hline 1 & 1327.9 & 0.06 & 18.33 & 0.001 & 0.00015 & 0.0002 \\
2 & 1327.9 & 0.19 & 11.53 & 0.20 & 0.07 & 40.62 \\
3 & 1327.9 & 0.09 & 7.63 & 0.20 & 0.00015 & 0.00003 \\
4 & 1327.9 & 0.01 & 13.19 & 0.10 & 0.04 & 13.35 \\
\hline
\end{tabular}


Table 8 Available nutrient flow from Melai sub-catchment to Lake Chini

\begin{tabular}{|c|c|c|c|c|c|c|c|}
\hline \multirow[t]{2}{*}{ Station } & \multicolumn{3}{|c|}{ Nutrient in soil $(\mu \mathrm{g} / \mathrm{g})$} & \multirow{2}{*}{$\begin{array}{l}\text { Erosion rate } \\
\text { (ton/ha/year) }\end{array}$} & \multicolumn{3}{|c|}{ Total nutrient flow (g/ha/year) } \\
\hline & $\mathrm{P}$ & $\mathrm{K}$ & $\mathrm{Mg}$ & & $\mathrm{P}$ & $\mathrm{K}$ & $\mathrm{Mg}$ \\
\hline 1 & 1.65 & 27.58 & 17.12 & 0.0002 & 0.0004 & 0.006 & 0.004 \\
\hline 2 & 1.51 & 21.09 & 4.90 & 40.62 & 61.34 & 856.68 & 199.04 \\
\hline 3 & 1.60 & 22.19 & 13.17 & 12.77 & 20.43 & 283.28 & 168.13 \\
\hline 4 & 3.23 & 27.37 & 47.54 & 0.00003 & 0.0001 & 0.001 & 0.001 \\
\hline Total & 8.0 & 98.2 & 82.7 & 53.4 & 81.8 & 1140.0 & 367.2 \\
\hline
\end{tabular}

Table 9 Total of soluble nutrient flow to the lake

\begin{tabular}{|c|c|c|c|c|c|c|c|c|c|}
\hline \multirow[t]{2}{*}{ Station } & \multicolumn{4}{|c|}{ Nutrient in soil $(\mu \mathrm{g} / \mathrm{g})$} & \multirow{2}{*}{$\begin{array}{l}\text { Soil loss } \\
\text { (ton/ha/year) }\end{array}$} & \multicolumn{4}{|c|}{ Total nutrient flow (g/ha/year) } \\
\hline & $\mathrm{PO}_{4}{ }^{3-}$ & $\mathrm{SO}_{4}{ }^{2-}$ & $\mathrm{NO}_{3}{ }^{-}-\mathrm{N}$ & $\mathrm{NH}_{4}^{+}-\mathrm{N}$ & & $\mathrm{PO}_{4}{ }^{3-}$ & $\mathrm{SO}_{4}{ }^{2-}$ & $\mathrm{NO}_{3}{ }^{-}-\mathrm{N}$ & $\mathrm{NH}_{4}^{+}-\mathrm{N}$ \\
\hline 1 & 12.60 & 1743.33 & 850.00 & 57.67 & 0.0002 & 0.003 & 0.38 & 0.19 & 0.01 \\
\hline 2 & 5.60 & 590.00 & 149.00 & 14.20 & 40.62 & 227.47 & 23965.9 & 6052.40 & 576.81 \\
\hline 3 & 5.30 & 540.00 & 44.00 & 11.80 & 12.77 & 67.66 & 6893.7 & 561.71 & 150.64 \\
\hline 4 & 7.30 & 390.00 & 139.00 & 14.40 & 0.00003 & 0.0002 & 0.010 & 0.004 & 0.0004 \\
\hline Total & 30.8 & 3263.3 & 1182.0 & 98.1 & 53.4 & 295.1 & 30860.0 & 6614.3 & 727.5 \\
\hline
\end{tabular}

Table 10 Heavy metals flow from Melai sub-catchment area to Lake Chini

\begin{tabular}{|c|c|c|c|c|c|c|c|c|c|c|c|c|c|}
\hline \multirow[t]{2}{*}{ Station } & \multicolumn{6}{|c|}{ Heavy metals in soil $(\mu \mathrm{g} / \mathrm{g})$} & \multirow{2}{*}{$\begin{array}{l}\text { Erosion rate } \\
\text { (ton/ha/year) }\end{array}$} & \multicolumn{6}{|c|}{ Total heavy metals flow (g/ha/year) } \\
\hline & Mn & $\mathrm{Pb}$ & $\mathrm{Cr}$ & $\mathrm{Cu}$ & $\mathrm{Co}$ & $\mathrm{Cd}$ & & $\mathrm{Mn}$ & $\mathrm{Pb}$ & $\mathrm{Cr}$ & $\mathrm{Cu}$ & $\mathrm{Co}$ & $\mathrm{Cd}$ \\
\hline 1 & 108.23 & 36.04 & 27.95 & 12.74 & 9.82 & 1.51 & 0.0002 & 0.024 & 0.008 & 0.006 & 0.003 & 0.002 & 0.0003 \\
\hline 2 & 18.05 & 30.16 & 3.61 & 2.59 & 9.02 & 0.91 & 40.62 & 733.19 & 1225.10 & 146.64 & 105.21 & 366.39 & 36.96 \\
\hline 3 & 932.93 & 259.71 & 18.94 & 50.25 & 13.99 & 1.32 & 12.77 & 11909.85 & 3315.48 & 241.79 & 641.49 & 178.60 & 16.85 \\
\hline 4 & 185.19 & 30.00 & 6.08 & 2.16 & 9.62 & 1.16 & 0.00003 & 0.0049 & 0.0008 & 0.0002 & 0.0001 & 0.0003 & 0.00003 \\
\hline Total & 1244.4 & 355.9 & 56.6 & 67.7 & 42.5 & 4.9 & 53.4 & 12643.1 & 4540.6 & 388.4 & 746.7 & 545.0 & 53.8 \\
\hline
\end{tabular}

$295.1 \mathrm{~g} / \mathrm{ha} /$ year, respectively. Based on Table 9, the $\mathrm{PO}_{4}{ }^{3-}$ flow into the lake is the highest from Station 2 and the lowest from Station 4, with values of $227.47 \mathrm{~g} / \mathrm{ha} / \mathrm{year}$ and $0.003 \mathrm{~g} /$ ha/year, respectively. The $\mathrm{SO}_{4}{ }^{2-}$ flow is the lowest from Station 4, at $0.010 \mathrm{~g} / \mathrm{ha} /$ year, and the highest at Station 2, at 23,965.9 g/ha/year. Station 2 has the highest total flow of $\mathrm{NO}_{3}{ }^{-}$into the lake, which is at 6,052.40 $\mathrm{g} / \mathrm{ha} / \mathrm{year}$, while Station 4 has the lowest, at $0.004 \mathrm{~g} / \mathrm{ha} / \mathrm{year}$. The flow of $\mathrm{NH}_{4}{ }^{+}-\mathrm{N}$ followed the same trend as $\mathrm{NO}_{3}{ }^{-}-\mathrm{N}$, where Station 2 had the highest, at $576.81 \mathrm{~g} / \mathrm{ha} /$ year and Station 4 had the lowest, at $0.0004 \mathrm{~g} / \mathrm{ha} /$ year. In general, the total nutrient flow into the lake is influenced by the rate of soil loss from the sub-catchment.

Heavy metals flow

The heavy metals content in the soil is shown in Table 10 . Mn has the highest concentration in the soil, followed by $\mathrm{Pb}, \mathrm{Cu}, \mathrm{Cr}, \mathrm{Co}$, and $\mathrm{Cd}$. Station 3 shows a high concentration of all studied heavy metals. Stations 3 and 2 show a higher amount of nutrient flow into Lake Chini compared with Stations 1 and 4. In terms of individual heavy metals, the highest concentration of nutrient to flow into the lake is $\mathrm{Mn}$, followed by $\mathrm{Pb}, \mathrm{Cu}, \mathrm{Cr}, \mathrm{Co}$, and $\mathrm{Cd}$. The high concentration of $\mathrm{Mn}$ is due to its naturally high content in the parent material in addition to its coprecipitation with $\mathrm{Fe}$ in weathered soils, which increases its concentration during the formation of oxide and oxyhydroxide. Higher rates of soil loss also contribute to higher amounts of heavy metal flow into the lake.

\section{Conclusions}

The estimated soil loss $(A)$ in the Melai sub-catchment is generally low due to low human activity; most the study area is covered by forested land use and most of the soil texture consists of clayey soil. Station 1 recorded the 
highest soluble nutrients in the soil, while Station 3 was the highest heavy metals. As an order the highest soil loss was from Station 2, rubber plantation, followed by Station 3, rubber and former mine, and the lowest was at Stations 1 and 4 , forest cover areas.

Overall, total flow of nutrients and heavy metals from the Melai sub-catchment into Lake Chini is expected low due to the low rate of soil loss. Low discharge of soluble nutrients and heavy metals due to minor land use activity in the study area showed that Melai River is considered as a stable sub-catchment for the present time.

Acknowledgments The authors wish to express their appreciation to the Ministry of Science, Technology and Environment for the Science Fund Grant 04-01-02-SF0589. Thanks are also due to the Faculty of Science and Technology, Universiti Kebangsaan Malaysia, for the use for the research facilities.

Open Access This article is distributed under the terms of the Creative Commons Attribution License which permits any use, distribution, and reproduction in any medium, provided the original author(s) and the source are credited.

\section{References}

Abdulla HH (1966) A study of development of Podzol profiles in Dovey Forest. Unpublished Ph.D. Thesis, University of Wales, Aberystwyth

APHA (1989) Standard methods for examination of water and wastewater, 117th edn. America Public Health Association, Washington, DC

Avery BW, Bascomb CL (1982) Soil survey laboratory methods. Soil survey technical MONOGRAPH No. 6, Harpenden

Baharuddin K (1988) Effect of logging on sediments yield in a hill dipterocarp forest in Peninsular Malaysia. J Trop Forest Sci 1(1):56-66

Batie SS (1983) Soil erosion. The Conservation Foundation, Washington, DC

Bhattarai R, Dutta D (2007) Estimation of soil erosion and sediments yield using GIS at catchment scale. Water Resour Manag 21:1635-1647

Bocco G (1991) Gully erosion: processes and models. Prog Phys Geogr 15:392-406

Bower KM (2010) Sustainability, natural capital, engineering, and geology: a case study of Coles County, IL, USA. Environ Earth Sci 61:549-563

De Neergaard A, Magid J, Mertz O (2008) Soil erosion from shifting cultivation and other smallholder land use in Sarawak, Malaysia. Agric Ecosyst Environ 125:182-190

Fortescue JAC (1979) Role of major and minor elements in the nutrition of plants, animals and man. In: Siegel FR (ed) Review of research on modern problems in geochemistry. United Nations Educational, Scientific and Cultural Organization, Paris, pp 57-88

Foster GR, McCool DK, Renard KG, Moldenhauer WC (1981) Conversion of the universal soil loss equation to SI Metric Units. J Soil Water Conserv 36:355-359
Kabata-Pendias A, Pendias H (2001) Trace elements in soil and plants, 4th edn. CRC Press, Boca Raton

Karageorgis AP, Sioulas A, Krasakopoulou E, Anagnostou CL, Hatiris GA, Kyriakidou H, Vasilopoulos K (2012) Geochemistry of surface sediments and heavy metal contamination assessment: messolonghi lagoon complex, Greece. Environ Earth Sci 65:1619-1629

Kirkby MJ (1980) Soil erosion: soil loss estimation. John Wiley \& Sons, New York

Lee GS, Lee HS (2006) Scaling effect for estimating soil loss in the RUSLE model using remotely sensed geospatial data in Korea. Hydrol Earth Syst Sci Discuss 3:135-157

Lopez TM, Mitchell Aide T, Scatena FN (1998) The effect of land use on soil erosion in the Guadiana Watershed in Puerto Rico. Carib J Sci 34(3-4):298-307

Mohd Ekhwan HJ, Toriman MB, Mokhtar OK, Muhd BG, Raihan T (2009) Short-term sediment yields from small catchment of Sungai Anak Bangi, Selangor. Geol Soc Mal Bull 55:55-59

Morgan RPC (2005) Soil erosion and conservation, 3rd edn. Blackwell, UK

Morgan RPC, Morgan DDV, Finney HJ (1982) Stability of agricultural ecosystems: documentation of a simple model for soil erosion assessment. International Institute for Applied Systems Analysis Collaborative Paper: $82-50$

Muhammad BG, Mohd EHJ, Toriman ZAR, Mir SI, Tan CC (2009) Flow characteristics of the Tasik Chini's feeder rivers, Pahang, Malaysia. Geol Soc Mal Bull 55:7-13

Murphy J, Riley JP (1962) A modified single solution method for the determination of phosphate in natural waters. Anal Chim Acta 27:31-36

Roose EJ (1977) Application of the universal soil loss equation of Wischmeier and Smith in West Africa. In: Greenland DJ, Lal R (eds) Soil conservation and management in the humid tropics. John Wiley \& Sons, London, pp 177-187

Roslan ZA, Tew KH (1997) Compilation of presented research papers on soil erosion issues in Malaysia. Department of Enviroment Malaysia, Malaysia

Sahibin AR, Tukimat L, Zulfahmi AR, Baba M, Adong L, Wan MRI, Muhd BG, Siti RA (2009) Physico-chemical characteristics and geochemical composition of soil from the former air terjun mine, Kota Tinggi, Johor. Geol Soc Mal Bull 55:27-31

Srivastava NK, Ram LC, Masto RE (2010) Role of selected riparian herbs in reducing soil erosion and nutrient loss under simulated rainfall. Environ Earth Sci 61:405-417

Sujaul IM (2009) Land use change, soil and water quality assessment of the Tasik Chini Catchment. Unpublished Ph.D. Thesis, Universiti Kebangsaan Malaysia

Tisdale SL, Nelson WL (1975) Soil fertility and fertilizers, 3rd edn. Mac Millan, New York

Wischmeier WH, Smith DD (1965) Predicting rainfall-erosion losses from ccropland east of Rocky Mountains: guide for selection of practises for soil and water conservation. Agricultural handbook 282. US Department of Agriculture

Wischmeier WH, Johnson CB, Cross BV (1971) A soil erodibility nomograph for farmland and construction sites. J Soil Water Conserv 26:189-193

Xu Y, Shao X, Kong X, Peng J, Cai Y (2008) Adapting the RUSLE and GIS to model soil erosion risk in a mountains karst watershed, Guizhou Province. China Environ Monit Assess 141:275-286

Yang D, Kanae S, Oki T, Koikel T, Musiake T (2003) Global potential soil erosion with reference to land use and climate change. Hydrol Process 17(14):2913-2928 